\title{
New Reform of Undergraduate Teaching to Cultivate Applied Talents
}

\author{
Li Yun Xing \\ School of Management \\ University of Jinan \\ Jinan, China \\ xly0502@163.com
}

\author{
Zhao Tong Zhu \\ Department of Road and Bridge \\ Shandong High-Speed Group \\ Jinan, China \\ sm_xingly@ujn.edu.cn
}

\begin{abstract}
Undergraduate teaching reform must be enforced with the development of society. This article analyzes the major characteristics of our current undergraduate teaching from the perspective of cultivating applied talents. It points out the current situation and the existing problems of undergraduate teaching and puts forward the corresponding countermeasures and suggestions.
\end{abstract}

Keywords: Practice teaching; Security mechanism ; Evaluation feedback mechanism

\section{INTRODUCTION}

New macroeconomic situation provides higher education the broad space to develop and at the same time puts forward higher requirements and challenges. In order to deal with the fierce market competition, institutions of higher learning should always adapt to the needs of social and economic development actively and regard the education quality as the lifeline of survival and development.

\section{MAIN PROBLEMS FOR OUR UNDERGRADUATE TEACHING}

\section{A. Unreasonable curriculum system and content}

1) Lack the concept of education service in profession setting: Currently, many universities don't really consider the actual demand of social change in setting professions. They can't pay close attention to the specific requirements of labor market and the real needs of students. Some don't make comprehensive analysis and planning from a long-term perspective and just follow the trend and fashion blindly.

2) Lack flexibility in choosing elective courses: Elective courses have many advantages. So many colleges have opened many elective courses, but there are a lot of problems.

First, the importance of elective courses is not outstanding. Elective courses of university in the proportion of the total score are too small and they don't be taken into consideration in evaluating some work such as scholarship. The space of college students' autonomous choice is very limit too. So teachers are not strict at attendance and examination.

Second, students don't know enough about the content of elective courses. So they choose courses according to the name of courses for granted or following the trend blindly so that their learning interest is not high.
Third, improper teaching method makes elective courses lose their due role. Dull atmosphere in the classroom and cramming teaching way make many students to lose interest in learning their selected courses.

3) Unreasonable teaching content for many courses:

First, at present, a lot of teaching content is repeated. A lot of content in different names appear in different courses, but essential content is similar. This will result in serious waste of resources.

Second, many textbooks are outdated, even a textbook used more than ten years. Many new theories and ideas reflecting the change of reality are not accepted. This will make teaching content to lag behind the development of the situation.

Third, there are many courses requiring remembering empty theories by rote. At present many courses are about empty theory mostly. And there are few courses that can help college students to solve practical problems and improve their interpersonal communication ability.

B. Old and single teaching method

With the development of teaching reform, most college teaching has changed from the original mode of blackboard and chalk to computer screen projection in multimedia classroom, but cramming teaching is the majority. Teachers impart knowledge and students listen passively. This old and single teaching method can't meet the various requirements of students.

First of all, one-way teaching goes ill with students' learning initiative fully. Students don't have the option to learn some knowledge according to their interests and specific circumstance, blindly following teachers' way of thinking.

Second, lecturing can't take care of individual differences. Teaching is to all the students and it is not conducive to teach students in accordance with their aptitude.

Finally, teaching provides more available knowledge and it lacks some opportunities for students to think independently. Teachers explain some questions in detail in order to form complete train of thought. Some teachers just impart students plenty of knowledge the whole class in order to try to make the students to master more knowledge. So students don't have enough time to digest and chance to explore the root of the problem.

\section{Imperfect social practice teaching system}

1) Lay less emphasis on practical teaching:

Undergraduate teaching should include many rich and colorful practical links, like production practice, course 
design, and graduation thesis. To a certain extent many universities have set these contents, but teachers and students don't pay enough attention to them. Many activities are only as a mere formality. In addition, a lot of content are changing according to the change of condition at will. What's more, there aren't strict, standardized and effective assessment methods for practical teaching and every student can pass easily and even get high scores.

2) Weak practice teaching: Teachers' practical guidance ability is insufficient. Many teachers go to universities to teach after graduation and they have little experience of practical production and management. They don't have abundant experience in guiding students' practice.

3) Many problems on the construction of practice base: First of all, a considerable part of our social practice teaching is done in our computer room in school. Universities buy a suite of application software according to the teaching content. Students use the software to operate on their own according to the tasks assigned by teachers. It can't connect with real enterprise outsides truly.

Secondly, most of us lack stable practice base outside school. Due to various reasons, many universities don't establish long-term, stable and friendly relations of cooperation. It's very difficult to provide students with the real opportunity to practice. Even if there are off-campus practice opportunities, many links will be no effect. At last, students hand in practice note and practice report and teachers don't care about specific practice process and actual harvest.

\section{NEW THOUGHT OF OUR UNDERGRADUATE TEACHING REFORM}

\section{A. Construct teaching quality guarantee system}

1) Organizational guarantee: We should set up education quality assurance mechanism from top to bottom in the whole school in order to guarantee our teaching quality and set down corresponding management system. We should found teaching committee led by the President and dean's office from the level of school. They focus on overall teaching reform and management mainly to ensure the quality of undergraduate teaching from macro level. Our institute should establish corresponding teaching management teams led by vice president in charge of teaching. They are responsible for daily teaching management, daily and mid-term teaching inspection. Each department should draw up specific teaching plan according to teaching program, carry out teaching research and reform and explore reasonable and practical teaching methods actively.

2) Teaching management system guarantee: Universities should set down a set of rigorous and flexible teaching management system according to specific circumstances including teaching plan management system, teacher evaluation system and teacher training system.

In teaching plan, we should clearly list training target, curriculum requirements, teaching process and some plan about practice teaching. We should establish scientific and strict management system. We should let students know these management systems from university entrance and do in accordance with these requirements.

Furthermore, universities should establish a set of perfect and reasonable teachers' assessment system. At present many universities adopt 360 degree evaluation method to evaluate teachers, including leaders, colleagues and students. Students play an important role in evaluating teachers. Theoretically, students are the object of teaching and they should have the right. Their suggestion should reflect teachers' teaching situation to the greatest extent. But it will produce a lot of problems in actual teaching evaluation. Some teachers are very strict with students so that students are bored. They will give lower scores when evaluating teaching. On the contrary, teachers who aren't strict with students may get higher scores. This will enable teachers to reduce the difficulty of examination and lower requirements in order to achieve high scores.

Students are a part of the evaluation of teachers' teaching quality. We should establish scientific teaching evaluation system according to various situations. This is very important for teachers to improve teaching enthusiasm.

Finally, universities should set down a complete set of teachers' training system including theory and practice training. At present our training mainly focuses on academic upgrading and improving the level of scientific research and there are less training about teaching. Even there is little, but it is about macro theory training mainly. There are little involving specific professional knowledge and teaching method. The development of society is very fast and many courses are new for teachers. Therefore, universities should train teachers through lectures, exchange of experience, teaching competition, mentoring and other forms. Teachers not only can teach but also will teach in this way.

3) Teaching resources guarantee: Teaching resources involve human, material and financial resources used in teaching. They are the foundation and necessity of teaching activities and they include a very wide range of content. This article will discuss them mainly from the construction of cyber source and library information.

Most teachers in universities aren't in office all the day and students can't find teachers to coach after class conveniently. Therefore universities should make full use of cyber sources such as course information platform is a good channel to communicate between teachers and students. Students can find teaching courseware, cases, exercises, online seminar and online question and answer by querying this platform. Universities can also release some information such as teaching management system and regulation. Through this network platform teachers can also upload advanced teaching experience, good teaching method and excellent teaching material content. Teachers can improve the efficiency and quality of preparing lessons by sharing excellent teaching resources.

Universities should make full use of various resources, cooperate with other organizations and update books and journals. In addition, we should strengthen the cooperation among colleges through interlibrary loan to enrich the database. 


\section{B. Construct teaching quality monitoring system}

1) Construct monitoring mechanism before class: Before class we should check teachers' teaching plan including teaching content, methods and process. On the other side students should preview lessons. Teachers should tell students the content and goal of next class and give some enlightening questions.

2) Construct monitoring mechanism in class: Teachers should pay special attention to classroom attendance. Students who are absent over a certain amount don't be allowed to participate final examination. Furthermore, students should listen carefully, think actively and answer questions. Teachers should take ordinary class performance into account.

3) Construct monitoring mechanism after class: Teachers should emphasize deep understanding and application of theories when assigning homework. Teachers should supervise and check students to finish homework independently. We can also assign teamwork to train cooperation ability. In addition, teachers should encourage students to take part in various competition activities to cultivate their creativity. These should be taken into consideration.

\section{Construct evaluation and feedback mechanism}

1) Form various evaluation body: Institutes should establish teaching evaluation committee to monitor and evaluate our teaching. Colleagues' comments should be considered. Besides, graduates are very important groups to evaluate our teaching. Schools, departments and teachers should try their best to keep close contact with graduates for a long time and establish tracking survey mechanism to investigate graduation condition. And we should listen to their advice about our professional setting, teaching content and others.

2) Use scientific and reasonable evaluation index: At present, teaching evaluation focuses on theoretical teaching mainly and there is less about practical teaching. Evaluation index should reflect the specific conditions of evaluated object systematically and thoroughly.

3) Adopt various evaluation methods: Evaluation methods should be diversified including qualitative evaluation methods and quantitative evaluation methods. For some professional foundation courses, we should separate test from teaching. For some courses combining with practice closely, we should put examination paper into practice.

\section{Conclusion}

Reform of undergraduate teaching is imminent. This article analyzes main problems of our current undergraduate teaching from the point of fostering applied talents. Based on this it puts forward the countermeasure, such as constructing teaching quality guarantee system, monitoring system and so on. But for many realistic problems, we should make further efforts to apply these to our teaching practice effectively. Only in this way can we cultivate more applied talents.

\section{ACKNOWLEDGMENT}

This work was supported by the project of teaching reform and research of university of Jinan (GJY1104).

\section{REFERENCES}

[1] Fanghai, the Comprehensive Quality Management System of College Teaching. China's Higher Education Research, 2007 (05). (in Chinese)

[2] Wang Lihua, Undergraduate Education Quality Guarantee Method, China Power Education 2008(06). (in Chinese)

[3] Xiong Zhixiang, Total quality management and higher education quality assurance. Higher Education Exploration,2002(3). (in Chinese)

[4] Li Yumei, Study on College Students' Integrated Practice Ability, Education Teaching and Research. 2003(2)

[5] Wang Qiguang, Liu Bingwen, Liu Jiyun. Exploration on Practice Teaching Reform and Ability training, Laboratory Research and Exploration,2004(1). 